\title{
Fog, Temperature and Air Quality Over the Metropolitan Area of São Paulo: a Trend Analysis from 1998 to 2018
}

\author{
André Cardoso Mühlig • Otto Klemm (i) • \\ Fábio Luiz Teixeira Gonçalves
}

Received: 29 July 2020 / Accepted: 9 October 2020 /Published online: 21 October 2020

(C) The Author(s) 2020

\begin{abstract}
This study investigates the long-term development of fog occurrences in the Metropolitan Area of São Paulo (MASP). Specifically, it analyzes the roles of meteorological and air quality parameters as potential drivers for fog formation. A dataset reaching back to the year 1933 shows that the overall trends of the annual fog occurrences (AFO) coincide with those of the annual mean temperature. Air quality data have been available since 1998, allowing us to perform a statistical analysis of the contributions of meteorology and air quality to AFO for the period from 1998 to 2018. The logistic regression model shows that the binary dependent variable (daily fog occurrence, FO) is explained by its independent predictors $\mathrm{PM}_{10}$, relative humidity $(\mathrm{rH})$, and daily minimum temperature $\left(\mathrm{T}_{\min }\right)$, in that order. FO was not found to be significantly influenced by atmospheric pressure $(\mathrm{aP})$ and nitrogen oxides $\left(\mathrm{NO}_{\mathrm{x}}\right)$. While the influence of $\mathrm{SO}_{2}$ was minor and associated with less confidence, it was negative. Potential causes for these surprising results are discussed. We conclude that the parameters $\mathrm{PM}_{10}, \mathrm{rH}$, and $\mathrm{T}_{\min }$ are significant drivers of fog formation in the MASP, whereby the total
\end{abstract}

\footnotetext{
A. C. Mühlig $\cdot$ O. Klemm $(\bowtie)$

Climatology Research Group, University of Münster,

Heisenbergstr.2, 48149 Münster, Germany

e-mail: otto.klemm@uni-muenster.de

F. L. T. Gonçalves

Institute of Astronomy, Geophysics and Atmospheric Sciences of the University of São Paulo, Rua do Matão 1226, Cidade

Universitária, São Paulo, SP 05508-090, Brazil
}

explanatory power of the drivers for the dichotomous variable $\mathrm{FO}$ is $16 \%$.

Keywords Air quality $\cdot$ Particulate matter $\cdot$ Climate change $\cdot$ Urban heat island $\cdot$ Logistic regression model

\section{Introduction}

The Metropolitan Area of São Paulo (MASP) is one of the largest urban agglomerations in South America and is considered to be the most important socioeconomic region in the southeast of Brazil. The area of the MASP extends over $7945 \mathrm{~km}^{2}$, and its estimated population of 21.5 million citizens is distributed over 39 conurbated municipalities, including São Paulo City, which is the most densely built and populated city (over 8000 inhabitants $\mathrm{km}^{2}$ ) in the country (EMPLASA 2017).

The MASP lies close to the Tropic of Capricorn $\left(23^{\circ}\right.$ $\left.33^{\prime} \mathrm{S}, 46^{\circ} 39^{\prime} \mathrm{W}\right), 80 \mathrm{~km}$ from the Atlantic Ocean, on a plateau at an altitude between 700 and $1000 \mathrm{~m}$ above mean sea level (MSL). Its climate is classified as humid subtropical (Cwa according to the Köppen scale) and characterized as having humid summer and dry winter seasons (Peel et al. 2007). The local weather is strongly influenced by sea and land breezes, by topographic features, and by interactions with urban heat island (UHI) effects (Vemado et al. 2016).

A meteorological phenomenon that is especially relevant for cities is fog, as incidences of fog directly affect ground, air, and sea transport by impairing the visibility and thus raising the likelihood of accidents 
(Vasconcellos et al. 2018). Fog is a meteorological phenomenon defined by conditions of horizontal visibility below $1 \mathrm{~km}$ on the ground as caused by hydrometeors (WMO 2017). Fog, which is a cloud with ground contact, typically has a liquid water content of $0.1-$ $0.2 \mathrm{~g} \mathrm{~m}^{-3}$ and droplet sizes around $10-\mu \mathrm{m}$ diameters. In comparison to elevated clouds, fog is usually much more concentrated with respect to air pollutants, because particulate and gaseous emissions from the surface have a more direct impact on fog chemistry than on the chemistry of higher clouds (Seinfeld and Pandis 2006).

Moreover, fog droplets interact directly with the incoming solar radiation, on the one hand through reflection, which increases the albedo, and on the other hand through absorption, which results in heating and increased latent heat fluxes within the fog layer (Boucher et al. 2013). Therefore, fog impacts the local climate. For example, Hartmann et al. (2013) state that the decline in the frequency of fog events in European cities has led to an increase in direct solar radiation at the ground and may, thus, be partially responsible for increased local warming effects.

In the time period between 1933 and 2008, the frequency of fog in the MASP was observed to decrease (Gonçalves et al. 2008). Thus, the goal of the current study is to prove whether the observed trend continued from 2008 through 2018, and, more importantly, determine what caused the observed overall trend. Gonçalves et al. (2008) suggested that regional warming led to the observed decrease of fog. Similarly, Da Rocha et al. (2015) also argue that regional processes account for the occurrence of fog in the MASP, but they suspect radiative rather than advective processes. However, other studies have suggested that both global warming and an increase in air quality have been driving observed decreases in fog at various sites worldwide, including the MASP (Vautard et al. 2009; Klemm and Lin 2016). Therefore, for the MASP, we will analyze the trends of fog in conjunction with the trends of meteorological and air quality parameters.

The main source of air pollutants in the MASP is street-traffic tailpipe emissions, caused by the city's over 7 million vehicles. Other sources are aviation, wood burning emissions from restaurants, construction and demolition, recovery and maintenance of outdoor road surfaces, domestic waste burning, as well as advection of pollutants from distant industrial activities, from biomass burning in peripheral urban areas, and from distant fires in the São Paulo State, Central Brazil, and the Amazon rainforest (Kumar et al. 2016). The Environmental Agency of São Paulo (Companhia Ambiental do Estado de São Paulo - CETESB) has monitored the MASP's air quality and traffic emissions since 1998, and in the last decade, several studies have concluded that although the vehicle fleet has increased by more than $100 \%$, most vehicular emission levels have decreased due to a series of implemented laws and regulations for tailpipe emissions and fuel blends (CETESB 2016; Silveira et al. 2015).

We will apply statistical modeling to develop an overview of whether fog formation is influenced by the air pollutants $\mathrm{SO}_{2}, \mathrm{NO}_{\mathrm{x}}$, and $\mathrm{PM}_{10}$ (acting as potential cloud condensation nuclei) as well as by the daily minimum temperature $\left(\mathrm{T}_{\min }\right)$, relative humidity $(\mathrm{rH})$, and atmospheric pressure $(\mathrm{aP})$. We make use of air quality data retrieved by CETESB and meteorological data provided from the Institute for Astronomy and Geophysics from the University of São Paulo (IAG/USP).

\section{Material and Methods}

We employed two different datasets covering two different research periods. Dataset_1 covers the 86-year period from 1933 until 2018. It contains the annual mean air temperature (AMT) and the annual fog occurrence (AFO). Both the air temperature and the fog occurrence were continuously measured, and the respective data were extracted from the database of the IAG/ USP.

The second dataset (Dataset_2) covers the 21-year period from 1998 through 2018. The period for Dataset_ 2 is much shorter than that of Dataset_1, but it contains, in addition to AMT and AFO, air quality data $\left(\mathrm{SO}_{2}, \mathrm{NO}_{\mathrm{x}}\right.$, and $\left.\mathrm{PM}_{10}\right)$ as routinely monitored by CETESB and further meteorological data $(\mathrm{rH}, \mathrm{aP})$ as provided by the IAG/USP.

\subsection{Meteorological Data}

The meteorological data (air temperature, relative humidity, atmospheric pressure, fog occurrence) were measured by the IAG/USP at their site on the Água Funda Park, $800 \mathrm{~m}$ above MSL and at $23^{\circ} 39^{\prime} 05.2^{\prime \prime} \mathrm{S}$, $46^{\circ} 37^{\prime} 23.4^{\prime \prime} \mathrm{W}$. The area itself (almost $750 \mathrm{ha}$ ) and its surroundings, especially the vegetation, did not change much since the 1930's. Dataset_1 was used to compare trends of AMT with trends of AFO in order to provide 
insight into the development of the two parameters over a very long time period. A similar study by Gonçalves et al. (2008) on the same dataset, though for a shorter period, documented an increase of AMT and a synchronous decrease of AFO.

For the analysis of Dataset_2, we also employed the dew point temperature to calculate the relative humidity. Overall, the daily minimum air temperature $\left(\mathrm{T}_{\min }\right)$, the daily mean relative humidity $(\mathrm{rH})$, and the daily mean atmospheric pressure (aP) were used to analyze potential correlations with fog occurrence and air quality parameters. Daily data on fog occurrence (FO) was available as a binary-coded variable. The variable describes whether, on a given day, a fog occurrence was sighted or not (yes $=1 ;$ no $=0$ ).

\subsection{Air Quality Data}

Data on air quality from 1998 until 2018 was downloaded directly from the São Paulo State Government's (CETESB) website and added to Dataset_2. The dataset is quality checked according to the new state air quality standards established by State Decree No. 59.113 from 2013-04-23 (CETESB 2016). Based on hourly data, we calculated the daily medians of the concentrations of $\mathrm{SO}_{2}, \mathrm{NO}_{\mathrm{x}}$, and $\mathrm{PM}_{10}$, as measured by 26 automatically monitoring stations in the MASP (Table 1). These stations are scattered through the most densely populated areas of the MASP, strategically installed in areas of heavy traffic and close to public places such as schools, hospitals, and parks, respectively (Fig. 1). We trust that the median of these stations is the best estimate of the overall air pollution in the MASP at a given time. To use either one single station or a group of stations would introduce issues such as missing data, gap filling, and potential overrepresentation of specific station types over others.

The monitoring of the parameters started mostly in 1998, and there is no inconsistency in the dataset. Specifically, there is no gap in the air pollutants' time series, because there was no malfunction of all stations at the same time and the median could be computed for each time step. The $\mathrm{PM}_{2.5}$ concentration was not used in this analysis because there are very large gaps (up to over 5 years) in the data set.

\subsection{Data Analysis}

Analysis of Dataset_1 is descriptive in nature, as we investigated temporal trends of AMT and AFO from 1933 through 2018 over the MASP. One aim of our study was to determine whether the corresponding trends of the two parameters continued or changed since 2008.

The analysis of Dataset_2 was focused on studying the importance of meteorological and air quality parameters as drivers of fog formation in the MASP. We employed binary logistic regressions, in which the emergence of a dependent, binary variable is linked with several predictor variables. The dichotomous parameter FO was defined as the dependent variable. The meteorological parameters $\left(\mathrm{T}_{\min }, \mathrm{rH}, \mathrm{aP}\right)$ along with the air quality parameters $\left(\mathrm{SO}_{2}, \mathrm{NO}_{\mathrm{x}}, \mathrm{PM}_{10}\right)$ were metrically scaled and processed as centered, standardized, independent variables acting as predictors in our model. We employed the "Enter" mode as our analysis method, meaning that all independent variables are analyzed equally, without discarding variables that exceed the significance level $(p=0.05)$.

\subsection{Logistic Regression}

The equation of the multivariate binary logistic regression is generally defined as follows:

$P(Y)=\frac{e^{B_{0}+B_{1} * X_{1}+B_{2} * X_{2}+B_{n} * X_{n}}}{1+e^{B_{0}+B_{1} * X_{1}+B_{2} * X_{2}+B_{n} * X_{n}}}$

with $P$ being the probability with values between 0 and 1. A statistical model can be formulated using Eq. 1, the predictors $X_{n}$ (first column in Table 2), and the variables $B_{n}$ (second column in Table 2) to predict the probability of fog occurrence. For the statistical significance ( $p$ value) of the predictors (column "Sig." in Table 2), the critical value was defined as $p \geq 0.05$.

\section{Results and Discussion}

\subsection{Results Dataset_1 (1933-2018)}

Figure 2 shows the time series of the annual mean air temperature (AMT) and the annual fog occurrence (AFO) in the period from 1933 through 2018. It clearly depicts an increase of the AMT and a decrease of the 


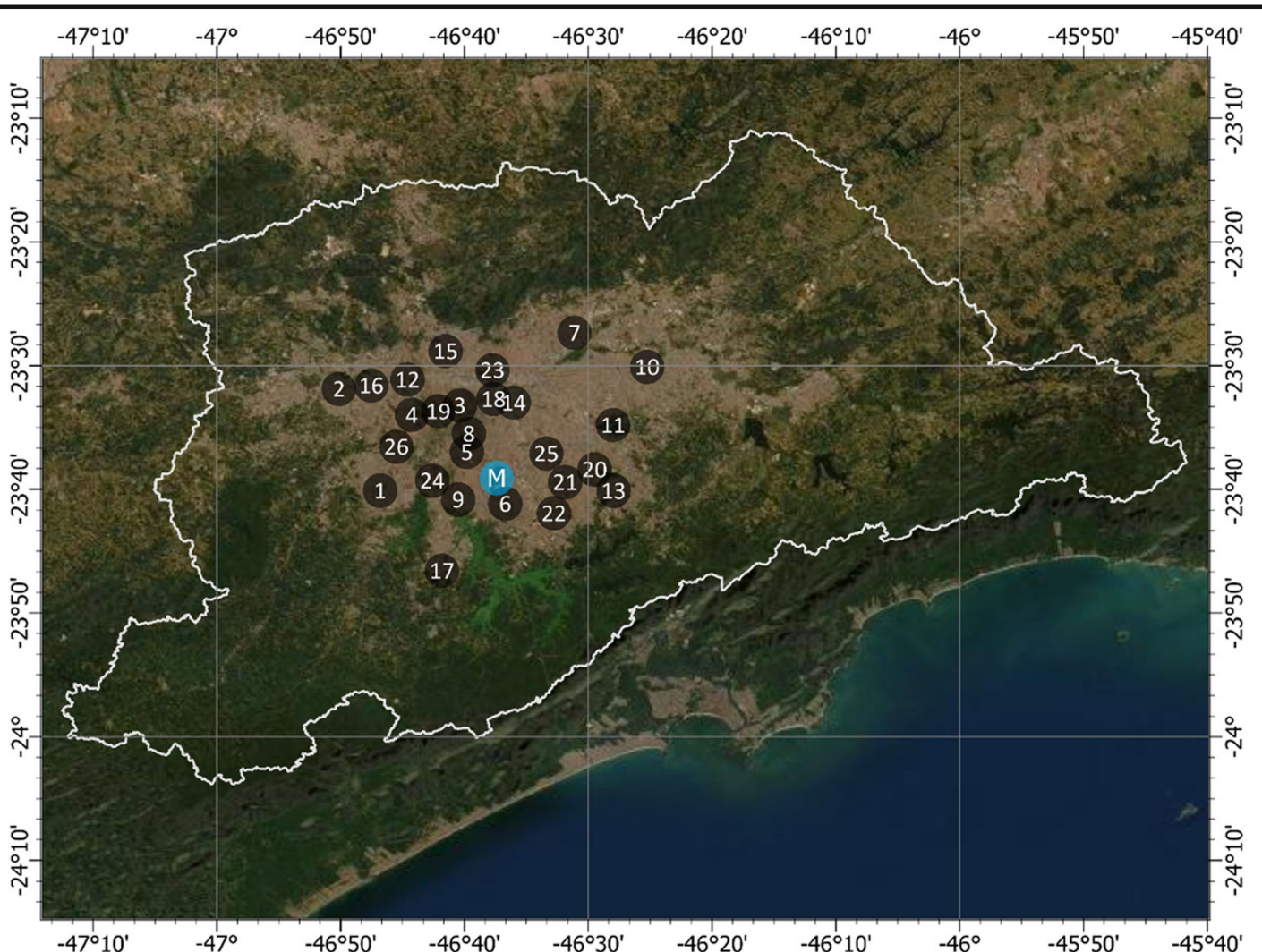

Fig. 1 Section of Southern Brazil with the metropolitan area of São Paulo (MASP, bold white boundary line). CETESB stations are indicated with their numbers (Table 1). The blue dot with "M" shows the IAG/USP monitoring site. Sources: Esri, DigitalGlobe,
GeoEye, Earthstar geographics, CNES/Airbus DS, USDA, USGS, AeroGRID, IGN, IBGE, CETESB, DataGeo and the GID User Community

et al. (2008). While the AMT continues its upward trend, the AFO continues to drop. The reasons for both trends in Dataset_1 are most likely related to global climate change and regional land use change, especially deforestation and urbanization. The almost tenfold growth of the population since the 1930s (Brazilian Institute of Geography and Statistics (IBGE) 2011) was accompanied by an increase in impervious surface area in the MASP (Freitas et al. 2007). This led to a change of the runoff regime and to a change of the meso- and microclimates in the MASP, specifically to the formation of urban heat islands (UHI) (Vemado et al. 2016). In addition, anomalies in the sea surface temperature (SST) of the Atlantic Ocean have been mentioned as potential drivers of the increase of AMT and the decrease of AFO (Gonçalves et al. 2008). Given the positive trend of the AMT in the MASP, it will likely continue to increase, and AFO trends will continue to decrease. 
Table 1 CETESB stations in the metropolitan area of São Paulo, monitored pollutants, and launch dates

\begin{tabular}{|c|c|c|c|c|c|}
\hline & Station name & $\mathrm{PM}_{10}$ & $\mathrm{NO}_{\mathrm{x}}$ & $\mathrm{SO}_{2}$ & Launch date \\
\hline 1 & Capão Redondo & $\mathrm{X}$ & $\mathrm{X}$ & - & 01.09 .2012 \\
\hline 2 & Carapicuíba & $\mathrm{X}$ & $\mathrm{X}$ & - & 27.02 .2012 \\
\hline 3 & Cerqueira César & $\mathrm{X}$ & $\mathrm{X}$ & $\mathrm{X}$ & 01.01.1998 \\
\hline 4 & Cid.UniversitáriaUSP-Ipen & - & $\mathrm{X}$ & - & 01.01 .1998 \\
\hline 5 & Congonhas & $\mathrm{X}$ & $\mathrm{X}$ & $\mathrm{X}$ & 01.01 .1998 \\
\hline 6 & Diadema & $\mathrm{X}$ & - & - & 01.01.1998 \\
\hline 7 & Guarulhos-Paço Municipal & $\mathrm{X}$ & $\mathrm{X}$ & - & 27.02.2012 \\
\hline 8 & Ibirapuera & $*$ & $\mathrm{X}$ & $*$ & 03.01.1998 \\
\hline 9 & Interlagos & $\mathrm{X}$ & $\mathrm{X}$ & $\mathrm{X}$ & 27.02 .2012 \\
\hline 10 & Itaim Paulista & $\mathrm{X}$ & $\mathrm{X}$ & - & 03.07 .2012 \\
\hline 11 & Itaquera & $*$ & $*$ & - & 09.08 .2007 \\
\hline 12 & Marg.Tietê-Ponte dos Remédios & $\mathrm{X}$ & $\mathrm{X}$ & $\mathrm{X}$ & 01.09 .2012 \\
\hline 13 & Mauá & $\mathrm{X}$ & $\mathrm{X}$ & - & 01.01 .1998 \\
\hline 14 & Mooca & $\mathrm{X}$ & - & - & 03.01 .1998 \\
\hline 15 & Nossa Senhora do Ó & $\mathrm{X}$ & - & - & 01.01 .1998 \\
\hline 16 & Osasco & $\mathrm{X}$ & $\mathrm{X}$ & $X$ & 01.01 .1998 \\
\hline 17 & Parelheiros & $\mathrm{X}$ & $\mathrm{X}$ & - & \\
\hline 18 & Parque D. Pedro II & $\mathrm{X}$ & $\mathrm{X}$ & $*$ & 01.11 .2004 \\
\hline 29 & Pinheiros & $\mathrm{X}$ & $\mathrm{X}$ & $\mathrm{X}$ & 01.09.1999 \\
\hline 20 & S. André-Capuava & $\mathrm{X}$ & - & - & 01.01.1998 \\
\hline 21 & S. André-Paço Municipal & $\mathrm{X}$ & - & - & 23.06 .2009 \\
\hline 22 & S. Bernardo-Centro & - & $\mathrm{X}$ & - & 02.04 .2014 \\
\hline 23 & Santana & $\mathrm{X}$ & - & - & 01.01.1998 \\
\hline 24 & Santo Amaro & $\mathrm{X}$ & - & - & 09.06.2009 \\
\hline 25 & São Caetano do Sul & $\mathrm{X}$ & $\mathrm{X}$ & $\mathrm{X}$ & 13.12 .2007 \\
\hline 26 & $\begin{array}{l}\text { Taboão da Serra } \\
\text { (X) Monitored parameter. } \\
\text { (*) Deactivated monitoring. Histo } \\
\text { (-) Not monitored parameter. }\end{array}$ & ly. & $\mathrm{X}$ & - & 01.01 .1998 \\
\hline
\end{tabular}

Data source: CETESB air quality monitoring network [2000-2018] (http://www.cetesb.sp.gov.br/ar/qualidade-do-ar/32-qualar)

Table 2 Result of the logistic regression

\begin{tabular}{lrll}
\hline Predictors $=X_{n}$ & B & S.E. & Sig. \\
\hline $\mathrm{T}_{\text {min }}$ & -0.382 & 0.033 & 0.000 \\
$\mathrm{aP}$ & 0.021 & 0.030 & 0.483 \\
$\mathrm{rH}$ & 0.587 & 0.039 & 0.000 \\
$\mathrm{PM}_{10}$ & 0.828 & 0.053 & 0.000 \\
$\mathrm{NO}_{\mathrm{x}}$ & -0.018 & 0.044 & 0.678 \\
$\mathrm{SO}_{2}$ & -0.117 & 0.039 & 0.003 \\
$\mathrm{Constant}$ & -1.628 & 0.035 & 0.000 \\
\hline
\end{tabular}

Yet, long-term countermeasures have been proposed. For example, planting suitable trees in the streets may lead to ground shading, cultivating green areas will enhance evapotranspiration, and installing solar panels on facades will help absorb radiation to convert it into electric energy (Johansson et al. 2013). In general, it appears that that the local governments have set their focus on climate change mitigation measures. The municipality of São Paulo was the first city of Brazil to establish a "Climate Law" to comply with the goals of the UNFCCC (Prefeitura da Cidade de São Paulo 2012). This law was sharpened in 2018, setting measures to reduce greenhouse gas emissions from the public 
Fig. 2 Annual mean temperature (black) and annual fog occurrence (blue) in the MASP from 1933 through 2018. Dotted lines show linear trends

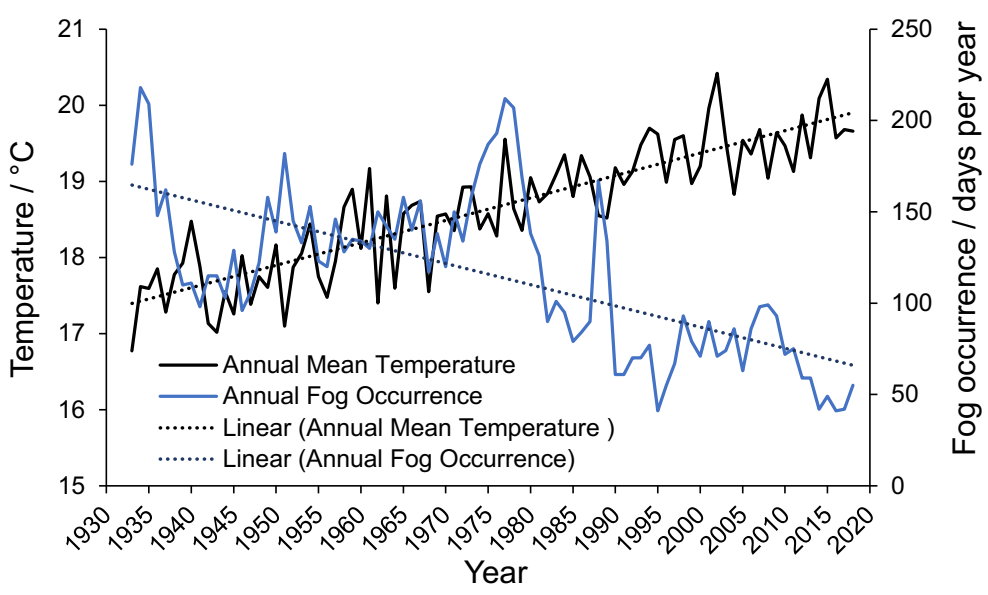

transport sector as well as from public waste management (Prefeitura da Cidade de São Paulo 2018). In the third quarter of 2019, the council of São Paulo ratified the "Plan of Climatic Action", the main strategy of which is to operate the city in line with the commitments of in the Paris Agreement (Prefeitura da Cidade de São Paulo 2020). Considering the socioeconomic influence of the municipality of São Paulo in the MASP, surrounding municipalities will likely follow its example.

\subsection{Results Dataset_2 (1998-2018)}

Figure 3 shows the annual median concentrations of the air pollutants $\mathrm{PM}_{10}, \mathrm{NO}_{\mathrm{x}}$, and $\mathrm{SO}_{2}$ between 1998 and 2018 in the MASP. The median concentrations exhibit a pronounced decreasing trend. The highest median of $\mathrm{SO}_{2}$ occurred in 2000 at about $42 \mu \mathrm{g} \mathrm{m}^{-3}$, while the lowest $\left(5.2 \mu \mathrm{g} \mathrm{m}^{-3}\right)$ was recorded from 2015 through 2018; the negative linear trend of $\mathrm{SO}_{2}$ is $\mathrm{dSO}_{2} / \mathrm{dt}=$ $-1.980 \mu \mathrm{g} \mathrm{m}^{-3}$ year $^{-1}\left(R^{2}=0.8927\right)$.

Regarding $\mathrm{NO}_{\mathrm{x}}$, its highest median concentration $\left(59 \mu \mathrm{g} \mathrm{m}^{-3}\right)$ was registered in 2001 and its lowest concentration $\left(19 \mu^{\mathrm{g} \mathrm{m}^{-3}}\right)$ in 2018 ; the negative linear trend is $\mathrm{dNO}_{\mathrm{x}} / \mathrm{dt}=-1.812 \mu \mathrm{g} \mathrm{m}^{-3}$ year $^{-1}\left(R^{2}=0.856\right)$. The highest median concentration of $\mathrm{PM}_{10}\left(43 \mu \mathrm{g} \mathrm{m}^{-3}\right)$ was recorded in 1998, whereas the lowest concentration $\left(22 \mu \mathrm{g} \mathrm{m}^{-3}\right)$ occurred in 2017 ; its negative linear trend is $\mathrm{dPM}_{10} / \mathrm{dt}=-0.957 \mu \mathrm{g} \mathrm{m}^{-3}$ year $^{-1}\left(R^{2}=0.808\right)$. Sulfur dioxide shows the strongest negative trend, followed by the trends of $\mathrm{NO}_{\mathrm{x}}$ and $\mathrm{PM}_{10}$.

According to CETESB, since industrial growth was limited the main source of atmospheric pollutants in the MASP has been vehicle emissions $\left(78 \%\right.$ of $\mathrm{NO}_{\mathrm{x}}, 43 \%$ of $\mathrm{SO}_{\mathrm{X}}$, and $40 \%$ of PM) (Andrade et al. 2015; Kumar et al. 2016; Nogueira et al. 2015; Vara-Vela et al. 2016). Although the vehicular fleet and the fuels in use have increased by more than $100 \%$ within the last decade, and although it is expected to further grow by about $6 \%$ year $^{-1}$, the air quality has improved following the implementation of a series of emission control measures enforced by the local and federal governments since the 1980s (Carvalho et al. 2015; Pérez-Martínez et al. 2015; Silveira et al. 2015). The Program for the Control of Vehicular Emission (PROCONVE-L) was introduced in 1986 for light-duty vehicles (LDV). Further on, PROCONVE-P was enacted in 1990 for heavy-duty vehicles (HDV). After the first phase of PROCONVEL (from 1988 through 1991), a total emission reduction of about $70 \%$ was realized, even though the emission standards for HDV only became legally effective in 1994. In 2002, a new law (Resolution CONAMA $315 / 2002$ from the Brazilian Environmental Council) established more strict tailpipe emission standards (Lucon and Goldemberg 2010), followed by PROMOT in 2003, which was another important piece of legislation with the objectives of controlling motorcycles' emissions and complementing the PROCONVE program (MMA 2013). Those laws and other conditions in Brazil stimulated vehicle manufacturers and the Brazilian market to introduce advanced, cleaner vehicles and fuels, which led to a considerable improvement of air quality (Noronha et al. 2016).

\subsection{1 $\mathrm{SO}_{2}$}

The atmospheric concentration of $\mathrm{SO}_{2}$ decreased mainly due to a reduction of the sulfur content of vehicular and industrial fuels (Silveira et al. 2015). Regulations to 
Fig. 3 Annual median concentrations of $\mathrm{PM}_{10}, \mathrm{NO}_{\mathrm{x}}$, and $\mathrm{SO}_{2}$ in the MASP for the period 1998-2018

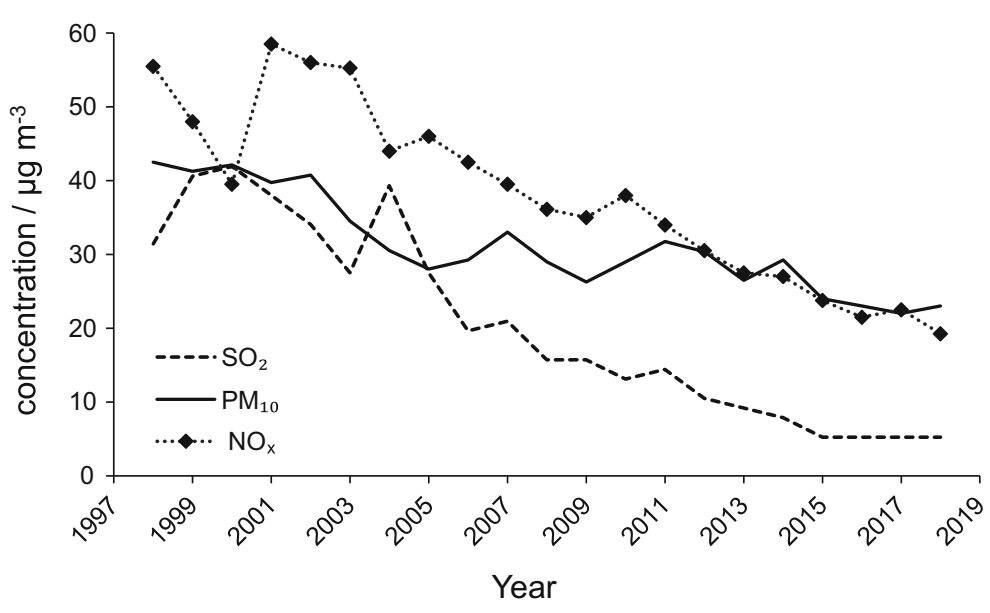

enforce the reduction of sulfur content in fuels were first implemented in the late 1970s, first affecting industrial sites and later on also vehicle emissions (Kumar et al. 2016).

The sulfur content in diesel fuel is a special case in Brazil. Before the introduction of the CONAMA 315Resolution in 2002, diesel fuel blends contained between 500 and $2000 \mathrm{mg} \mathrm{kg}^{-1}$ of sulfur. When the resolution came into effect in 2003, the national oil company Petrobras, which is the main producer of fossil fuels in the country, did not immediately supply the market with the mandatory S50-diesel fuel (= diesel with $50 \mathrm{mg} \mathrm{kg}^{-1}$ of sulfur). They argued that they only had to follow a prior regulation by the Agência Nacional do Petróleo (ANP), the Brazilian National Oil Agency. Subsequently, the Federal State of São Paulo filed a lawsuit against Petrobras and ANP and eventually enforced them to provide S50-diesel to the Brazilian market starting in 2003 (Lucon and Goldemberg 2010). This process could explain the abrupt decrease of the $\mathrm{SO}_{2}$ concentration in air after 2004 (Fig. 3).

However, as HDVs remained a major source of $\mathrm{SO}_{2}$ and other pollutants, the local government took further action in 2008 and prohibited HDV traffic in the central sections of the MASP (Kumar et al. 2016). As the outcome was, again, considered to be unsatisfactory, a new phase of PROCONVE was implemented, so that starting in 2012, S10-diesel has to be provided to the market (Lucon and Goldemberg 2010).

\subsection{2 $\mathrm{NO}_{x}$}

The $\mathrm{NO}_{\mathrm{x}}$-emissions also decreased due to the control policies described above and due to improvements of vehicle technology. In the first phase of PROCONVE-L (L-1), between the years 1988 and 1991, technological innovations (i.e., the introduction of three-way catalytic converters) led to the reduction of exhaust gases, which diminished $\mathrm{NO}_{\mathrm{x}}$ emissions. Later, the fourth phase of PROCONVE-L (L-4, from 2005 till 2008) focused on reducing ozone precursor compounds, hydrocarbons and $\mathrm{NO}_{\mathrm{x}}$ through new technologies in vehicles (i.e., optimized combustion chamber, electronic and increased pressure fuel injection). In the fifth phase (L-5 from 2009 through 2013), the emission policies were further sharpened. As a result, the $\mathrm{NO}_{\mathrm{x}}$ emissions were reduced to $48 \%$ and $42 \%$ for LDVs and HDVs, respectively. However, regarding vehicular emissions from HDVs, PROCONVE-P aided by the reduction of $\mathrm{NO}_{\mathrm{x}}$ emissions especially in its fifth and sixth phases (P-5, from 2003 to 2008 and P-6, from 2009 to 2011) (Nogueira et al. 2015).

\subsection{3 $P M_{10}$}

Important contributors to the $\mathrm{PM}_{10}$ mass concentration are primary, natural aerosol particles such as dust and sea salt. Further, over $40 \%$ of the respective particle mass is secondary material which is formed in atmospheric processes from precursor gases. These gases are primarily hydrocarbons that originate largely from vehicle emissions (Vara-Vela et al. 2016). Another trafficrelated source is not related to engine exhaust: Resuspension of material from dry roads and abrasion of brakes, tires, and clutches introduces nonexhaust traffic-related particles into the ambient air that contribute to the $\mathrm{PM}_{10}$ concentration (Grigoratos and Martini 2014). The respective emissions are estimated to be of 
the same magnitude as that of tailpipe emissions. In addition, human food preparation also contributes to the generation of $\mathrm{PM}_{10}$. The MASP hosts a large number of restaurants (mostly pizzerias operating on wood stoves or steakhouses using charcoal ovens), the emissions of which are not under any emission controls (Kumar et al. 2016). A similar situation applies to home cooking and machines used for construction. Although a few respective case studies do exist, the role of anthropogenic emissions, i.e., cooking, construction and airport emissions, to the $\mathrm{PM}_{10}$ concentration and other pollutant levels in the MASP should not be underestimated.

\subsubsection{Minimum Temperature, Relative Humidity, and Atmospheric Pressure}

Figure 4 shows the annual medians of the daily minimum temperature $\left(\mathrm{T}_{\mathrm{min}}\right)$ and the annual mean of the relative humidity $(\mathrm{rH})$ in the respective period. The lowest annual median of $\mathrm{T}_{\min }\left(15.2^{\circ} \mathrm{C}\right)$ was registered in the year 1999 , while the maximum $\left(17.8^{\circ} \mathrm{C}\right)$ occurred in 2015. Assuming a linear trend of $\mathrm{T}_{\min }$ since 1998, it's slope is positive $\left(\mathrm{dT}_{\min } / \mathrm{dt}=0.0084{ }^{\circ} \mathrm{C}\right.$ year ${ }^{-1}, R^{2}=$ $0,0069)$. The lowest annual median $(71 \%)$ of $\mathrm{rH}$ was in the year 2007, the highest (85\%) was recorded in 1999. Since 1998, rH decreases on average. Accepting a linear negative trend for $\mathrm{rH}$, its slope is $\mathrm{drH} / \mathrm{dt}=$ $-0.1395 \%$ year $^{-1}, R^{2}=0.054$. A negative trend of aP (not shown in detail) has also been detected $(\mathrm{daP} / \mathrm{dt}=-$ $0.2331 \mathrm{hPa}$ year $\left.^{-1}, R^{2}=0.2775\right)$. The annual medians do exhibit large fluctuations over the years, and they do not correlate with the decrease of AFO.

With respect to our findings from descriptive statistics of Dataset_2, we summarize that the concentrations of $\mathrm{PM}_{10}, \mathrm{NO}_{\mathrm{x}}$, and $\mathrm{SO}_{2}$ decreased between 1998 and 2018, while $\mathrm{T}_{\min }$ increased. Note that the relative humidityalso decreased. To study these results and their potential impact on AFO in more detail, we performed the statistical analysis of Dataset_ 2 via logistic regression.

\subsection{Results of the Logistic Regression}

We performed the logistic regression on SPSS and chose the "Enter" method for further analysis. First, the significance of our regression model is calculated by the Omnibus Test of Model Coefficients. It is equivalent to the chi-square test and provides a statement about the explanatory power of the model. The model is, according to the chi-square test (chi-square $=747.31$; degrees of freedom $=6$; significance is $p=0.000$ ) significant and, therefore, useful for further analysis. The goodness of fit of the model was calculated on the basis of Nagelkerke's pseudo $R^{2}$. If a full model predicts the outcome perfectly, then the Nagelkerke's pseudo $R^{2}=1$ (UCLA - Statistical Consulting Group n.d., last access: 2019-11-23). In our model $R^{2}$ Nagelkerke $=0.164$, which indicates that the model explains only $16.4 \%$ of the observed outcome. Further, the model's relevance is estimated using the effect size $f$ according to Cohen (1992):

$f=\sqrt{\frac{R^{2}{ }_{\text {Nagelkerke }}}{1-R^{2}{ }_{\text {Nagelkerke }}}}$

Corresponding to Cohen's classification system, our model has a strong effect $(f=0.44)$ (Cohen 2009).

Table 2 shows the results of the binary logistic regression. Here, the predictors $\left(X_{n}\right)$ are in the first column, $B$ 's are the generated coefficients for the predictors and for the constants in the model (Eq. 1), S.E. values in the third column are the standard errors around the coefficients $(B)$, and Sig. in the fourth column is the statistical significance of each coefficient.

The Sig. values of the independent variables, $T_{\min }$, $\mathrm{rH}$, and $\mathrm{PM}_{10}$ area equal zero $(p=0)$, meaning that these parameters are significant predictors of fog occurrence $(\mathrm{FO}=1)$. For $\mathrm{SO}_{2}$, the significance of 0.003 does not exceed the critical value (defined as $p=0.05$ ), meaning that its influence is considered as significant as well, but at a lower level compared to that of the former variables.

The significance levels of aP $(p=0.483>0.05)$ and $\mathrm{NO}_{\mathrm{x}}(p=0.678>0.05)$ exceed the critical value. Their influence on fog formation is very likely of random character. Thus, they are not implemented into the regression Eq. 3 (Bittmann 2015; Zürich 2018). Substituting the $B_{n}$ values and the $X_{n}$ values in Eq. 1 with their respective coefficients and significant predictors (Table 2), we arrive at the following equation:

$P(\mathrm{Fog}=1)=\frac{\mathrm{e}^{-1.628-0.382 * \mathrm{~T}_{\min }+0.587 * \mathrm{rH}+0.828 * \mathrm{PM}_{10}-0.117 * \mathrm{SO}_{2}}}{1+\mathrm{e}^{-1.628-0.382 * \mathrm{~T}_{\min }+0.587 * \mathrm{rH}+0.828 * \mathrm{PM}_{10}-0.117 * \mathrm{SO}_{2}}}$

The logistic regression model was operated with daily data. Most of the model results (Eq. 3) are conceivable with general meteorological and climatological reasoning. For example, it is obvious that a day with high air humidity $\mathrm{rH}$ is more likely to be (or become) a 
Fig. 4 Annual medians of daily minimum temperature (red line) and daily mean relative humidity (purple line) in the MASP for the period 1998-2018

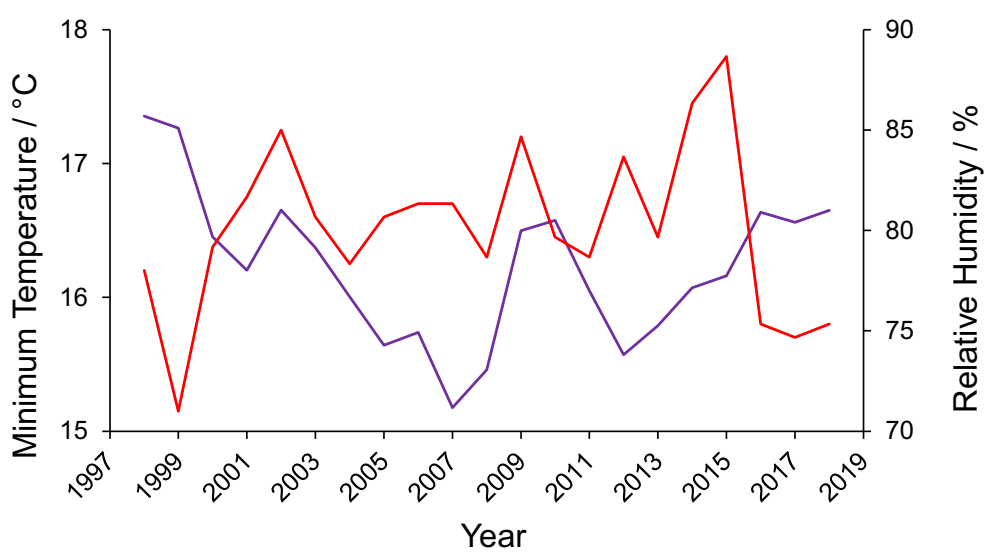

foggy day than a drier day. Correspondingly, the driver $\mathrm{T}_{\text {min }}$ exhibits a negative coefficient in Eq. 3, meaning that a relatively low daily minimum air temperature fosters the formation of fog. The roles of these meteorological variables as drivers of fog formation is unequivocal, fog cannot form in an air mass that is warm and dry.

The roles of the air pollution parameters are less straightforward when analyzing their influence on fog on a daily basis than it was for the annual averages (section 3.1). For example, a high concentration of $\mathrm{SO}_{2}$ leads to the formation of large amounts of cloud condensation nuclei (CCN) after gas-phase oxidation of $\mathrm{SO}_{2}$ to $\mathrm{H}_{2} \mathrm{SO}_{4}$. If $\mathrm{rH}$ raises, these $\mathrm{CCN}$ facilitate the formation of a large number of small fog droplets that effectively scatter light and lead to a strong reduction of the horizontal visibility. In that sense, high $\mathrm{SO}_{2}$ should be correlated with high FO. However, Eq. 3 shows a contradictory result, i.e., a negative regression between $\mathrm{SO}_{2}$ and FO $(B=-0.117 ; p=0.003)$. There are two possible reasonings to explain these findings. First, once fog is formed in conjunction with $\mathrm{SO}_{2}$ as described above, the liquid phase is a further effective sink for $\mathrm{SO}_{2}$. It will be completely scavenged from the gas phase and further oxidized to $\mathrm{H}_{2} \mathrm{SO}_{4}$. The remaining very small concentrations of gaseous $\mathrm{SO}_{2}$ in the gas phase cannot be detected any more with conventional analyzers, so that the correlation between $\mathrm{SO}_{2}$ and $\mathrm{FO}$ is disguised. Second, the data base of our analysis is, both spatially and temporally, not perfectly synchronous. While the FO data are collected at one single location, the $\mathrm{SO}_{2}$ data are averages over the entire MASP. Further, fog may have been detected on a day for only a short time period, while the $\mathrm{SO}_{2}$ data are averaged over 24-h periods. Such disalignment may lead to statistical misinterpretation.
The $\mathrm{PM}_{10}$ concentration shows a positive regression with FO (Eq. 3). This result is reasonable because $\mathrm{PM}_{10}$ can be regarded as a proxy for CCN. Although this last statement should be made cautiously in the context of fog formation, because it is not the mass concentration of aerosol particles that defines their efficacy to act as $\mathrm{CCN}$ rather than their number concentration, hygroscopicity, and sizes, the effect of $\mathrm{PM}_{10}$ on FO is, statistically speaking, rather strong, even on a daily basis (coefficient $B=0.828$ ).

The role of $\mathrm{NO}_{\mathrm{x}}$ is somewhat between that of $\mathrm{SO}_{2}$ and $\mathrm{PM}_{10}$. Nitrogen oxides are, under certain conditions, precursors for $\mathrm{CCN}$ and thus for the formation of fog, although their efficacy is much lower than that of $\mathrm{SO}_{2}$. They cannot be regarded as a proxy for $\mathrm{FO}$ as $\mathrm{PM}_{10}$ can. Overall, their contribution is not significant $(B=-0.018 ; p=0.678)$.

Our regression model states that aP has no significant contribution to fog formation. We did not further study if the general weather situation, i.e., the presence of high-pressure or low-pressure systems, plays any role in the formation of radiation fog or advected fog. The general picture suggests that the atmospheric pressure is not a significant driver for the overall occurrence of fog also on a yearly basis. Overall, the regression model suggests that high concentrations of particulate matter $\left(\mathrm{PM}_{10}\right)$ along with the low presence of high relative humidity $(\mathrm{rH})$ and minimal temperatures $\left(\mathrm{T}_{\min }\right)$ have a strong influence on fog formation mechanisms over the MASP. Statistical uncertainties remain. For instance, both goodness of fit $\left(R_{\text {Nagelkerke }}^{2}=0.164\right)$ and effect size $(f=$ $0.44)$ demonstrate the limitation of the explanatory power of the model. Therefore, the interpretation of the results should be exercised with caution. 


\section{Conclusion}

Most of the results of our overview trend analysis for assessing the occurrence of fog in the MASP under the influence of meteorological drivers and air pollution are highly consistent with scientific understanding of fog formation: The decrease of AFO over decades is associated with increasing temperatures and decreasing relative humidity. Ongoing urbanization and the regional imprint of global change are, thus, rather obvious contributors to the observed trend of AFO. This is evident from visual inspection of the longer historical dataset (since 1933) and the shorter dataset (since 1998) as well as from statistical analysis of the latter set.

Further drivers are increasing air quality in the MASP. The annual trends of air quality parameters (Fig. 3) and their synchronicity with AFO (Fig. 2) are striking. The statistical analysis of the shorter data set with a logistic regression partly supports these observations. $\mathrm{PM}_{10}$ is the strongest driver of $\mathrm{AFO}$, followed by $\mathrm{rH}$ and $\mathrm{T}_{\text {min }}$. This indicates that both warming and increasing air quality lead to the decrease of AFO in the MASP.

For $\mathrm{PM}_{10}$, its dominant role is conceivable as it is a proxy for $\mathrm{CCN}$, which are effective drivers for reduced visibility and fog formation whenever $\mathrm{rH}$ is very high (Maurer et al. 2019). Statistically, $\mathrm{NO}_{\mathrm{x}}$ is not a significant contributor to the AFO trend. This result is not surprising, because nitrogen oxides are only indirectly associated with the formation of PM and CCN. Note, however, that the $\mathrm{NO}_{\mathrm{x}}$ decreases together with AFO.

Due to its chemical properties, we expected that increasing levels of $\mathrm{SO}_{2}$ would contribute positively to fog formation. Figure 3 shows a strong decrease of the yearly $\mathrm{SO}_{2}$ concentration, which occurs together with the decrease of AFO (Fig. 2), suggesting a positive correlation between these two parameters. The logistic model results, however, do not support this result, even suggests an opposite relation. At this point, it is not unequivocally clear why the logistic regression does not confirm this picture. We speculate that the $\mathrm{SO}_{2}$ concentration is, in the MASP, more closely related to the formation of haze situations (visibility $1-5 \mathrm{~km}$ ) with lower humidity associated with radiative processes, while situations of even lower visibility $(<1 \mathrm{~km})$ are mostly associated with humidity advected from the Atlantic Ocean (Da Rocha et al. 2015). Also, there may be a temporal and spatial mismatch between the observation of fog (one location, often one point in time during a day) and the $\mathrm{SO}_{2}$ data (daily medians over the entire MASP). The role of $\mathrm{SO}_{2}$ is, thus, not entirely comprehensible. We speculate that an analysis based on data with better spatial and temporal allocation would change the picture considerably.

The atmospheric pressure (aP) does not contribute significantly to fog formation. Likely, a more detailed analysis of fog occurrence during the various seasons of the year would lead to a different result, because the weather systems in winter lead to a higher fog frequency than those in summer. It has been shown for other regions that changing circulation patterns may lead to changing patterns of fog occurrence (e.g., LaDochy and Witiw 2012).

It is not expected that the drivers we examined can fully explain the formation (or nonformation) of fog. The explanatory power of our model is only $16 \%$. Further note that, strictly speaking, most parameters analyzed in this and other studies are nothing more than proxies of potential drivers of fog formation. Only for the meteorological parameter $\mathrm{rH}$, a direct and causal effect on fog is expected, because fog occurs only at high-enough $\mathrm{rH}$. However, such high $\mathrm{rH}$ is rather difficult to measure accurately so that these data are often not reliable. Therefore, the air temperature is an attractive proxy: With increasing temperature and all other conditions being constant, $\mathrm{rH}$ decreases. In a similar fashion, $\mathrm{SO}_{2}$ or $\mathrm{NO}_{\mathrm{x}}$ are not at all direct drivers of fog. Only their oxidation and subsequent formation of secondary aerosol particles drives the formation of cloud condensation nuclei $(\mathrm{CCN})$. A larger number of $\mathrm{CCN}$ leads, with all other conditions being constant, to a larger number of yet smaller fog droplets. Klemm and Lin (2016) showed that this effect leads to a reduction of the horizontal visibility and thus enforces fog. The $\mathrm{PM}_{10}$ concentration, which is measured in São Paulo and many other places, is the only available proxy for $\mathrm{CCN}$ in long-term time series. However, the correlation between $\mathrm{PM}_{10}$ and $\mathrm{CCN}$ is in many cases poor and therefore the $\mathrm{PM}_{10}$ concentration is a rather nonspecific proxy for $\mathrm{CCN}$. Given these limitations we are impressed by the strong role $\mathrm{PM}_{10}$ plays in driving the formation of fog in the MASP. We conclude that the model performance (goodness of fit $R^{2}$ Nagelkerke $=0.164$, effect size $f=$ 0.44 ) is acceptable to provide an overview of the parameters driving fog trends in the MASP.

More detailed analyses in the future should include the seasonality of fog and meteorological conditions. This may help to elucidate the role of regional weather 
systems and their dynamics in the context of how climate change drives fog occurrence in the MASP. Further, nonlinear models should be employed. Hůnová et al. $(2018,2020)$ found for their studies in the Czech Republic that $\mathrm{rH}, \mathrm{SO}_{2}, \mathrm{NO}_{\mathrm{x}}$, air temperature and seasonality were explanatory variables for fog trends. However, they also found that the number of stations analyzed and the lengths of the observation periods played important roles, just like the seasonality. Maurer et al. (2019) found for datasets from Taiwan that the influence of $\mathrm{PM}_{10}$ on fog was stronger when the $\mathrm{PM}_{10}$ concentration was lower, while $\mathrm{rH}$ was more important in more polluted air masses.

Future datasets should also include the quantification of the horizontal visibility rather than just the dichotomous parameter of presence/absence of fog during a given day. Also, it should be considered to use exclusively hourly air quality data measured at the same times when fog was observed. We also suggest that intensive campaigns should be performed to produce more detailed data on air chemistry, the chemical composition of $\mathrm{CCN}$ and fog, and their particle size distributions in order to quantify how local and regional air pollution influence the formation and density of fog.

Acknowledgments This study was supported by a grant from the Brazilian Center of the University of Münster (WWU) to André Cardoso Mühlig, which is gratefully acknowledged. We also thank Celeste Brennecka for language-editing of this manuscript. An anonymous reviewer on a previous version of the manuscript helped to improve it considerably, thank you!

Funding Open Access funding enabled and organized by Projekt DEAL.

\section{Compliance with Ethical Standards}

Competing Interest The authors declare that they have no conflict of interest.

Open Access This article is licensed under a Creative Commons Attribution 4.0 International License, which permits use, sharing, adaptation, distribution and reproduction in any medium or format, as long as you give appropriate credit to the original author(s) and the source, provide a link to the Creative Commons licence, and indicate if changes were made. The images or other third party material in this article are included in the article's Creative Commons licence, unless indicated otherwise in a credit line to the material. If material is not included in the article's Creative Commons licence and your intended use is not permitted by statutory regulation or exceeds the permitted use, you will need to obtain permission directly from the copyright holder. To view a copy of this licence, visit http://creativecommons.org/licenses/by/4.0/.

\section{References}

Andrade, M. D. F., Ynoue, R. Y., Freitas, E. D., Todesco, E., Vara Vela, A., Ibarra, S., Martins, L. D., Martins, J. A., \& Carvalho, V. S. B. (2015). Air quality forecasting system for southeastern Brazil. Frontiers in Environmental Science, 3. https://doi.org/10.3389/fenvs.2015.00009.

Bittmann, F. (2015). Einführung in die Logistische Regression mit SPSS. Resource document, http://www.felix-bittmann. de/downloads/artikel/einfuehrung_logit_regression_mit_ SPSS.pdf. Accessed 10 April 2019.

Boucher, O., Randall, D., Artaxo, P., Bretherton, C., Feingold, G., Forster, P., Kerminen, V.-M.V.-M., Kondo, Y., Liao, H., Lohmann, U., Rasch, P., Satheesh, S.K., Sherwood, S., Stevens, B., Zhang, X.Y., Zhan, X.Y. (2013). Clim. Chang. 2013 Phys. Sci. Basis. Contrib. Work. Gr. I to Fifth Assess. Rep. Intergov. Panel Clim. Chang, hapter 7 - Clouds and aerosols,. 571-657. Resource document. Cambridge University Press, https://doi.org/10.1017 /CBO9781107415324.016, Accessed 23 July 2020.

Brazilian Institute of Geography and Statistics (IBGE) (2011). Census 2010: Characteristic of the population and household. https:/www.ibge.gov.br/en/statistics/social/labor/18391-2010population-census.html?=\&t=o-que-e, Accessed 23 July 2020.

Carvalho, V. S. B., Freitas, E. D., Martins, L. D., Martins, J. A., Mazzoli, C. R., \& Andrade, M. de F. (2015). Air quality status and trends over the metropolitan area of São Paulo, Brazil as a result of emission control policies. Environmental Science \& Policy, 47, 68-79. https://doi.org/10.1016/j. envsci.2014.11.001.

CETESB (2016). Relatório de qualidade do ar no estado de São Paulo. Resource document, https://cetesb.sp.gov.br/wpcontent/uploads/2017/09/relatorio-ar-2016.pdf, Accessed 11 November 2019.

Cohen, J. (1992). A power primer. Psychological Bulletin, 112, 155.

Cohen, J. (2009). Statistical power analysis for the behavioral sciences (2nd ed.). New York: Psychology Press.

Da Rocha, R. P., Gonçalves, F. L. T., \& Segalin, B. (2015). Fog events and local atmospheric features simulated by regional climate model for the metropolitan area of São Paulo, Brazil. Atmospheric Research, 151, 176-188. https://doi. org/10.1016/j.atmosres.2014.06.010.

EMPLASA, E.P. de P.M.S. (2017). Região Metropolitana de São Paulo [WWW Document]. Sobre a Região Metrop. São Paulo. https://emplasa.sp.gov.br/RMSP. Accessed 11 November 2019.

Freitas, E. D., Rozoff, C. M., Cotton, W. R., \& Silva Dias, P. L. (2007). Interactions of an urban heat island and sea-breeze circulations during winter over the metropolitan area of São Paulo, Brazil. Boundary-Layer Meteorology, 122, 43-65. https://doi.org/10.1007/s10546-006-9091-3.

Gonçalves, F. L. T., da Rocha, R. P., Fernandes, G. P., \& Petto, S. (2008). Drizzle and fog analysis in the São Paulo Metropolitan Area: changes 1933-2005 and correlations with other climate factors. Die Erde, 139, 61-76.

Grigoratos, T., Martini, G. (2014). Non-exhaust traffic related emissions - brake and tyre wear PM. https://doi.org/10.2790 /21481. 
Hartmann, D.J., Klein Tank, A.M.G., Rusticucci, M., Alexander, L. V, Brönnimann, S., Charabi, Y.A.-R., Dentener, F.J., Dlugokencky, E.J., Easterling, D.R., Kaplan, A., Soden, B.J., Thorne, P.W., Wild, M., Zhai, P. (2013). Observations: atmosphere and surface. Clim. Chang. 2013 Phys. Sci. Basis. Contrib. Work. Gr. I to fifth assess. Rep. Intergov. Panel Clim. Chang. 159-254. https://doi. org/10.1017/CBO9781107415324.008.

Hůnová, I., Brabec, M., Malý, M., \& Valeriánová, A. (2018). Revisiting fog as an important constituent of the atmosphere. Science of the Total Environment, 636, 1490-1499.

Hůnová, I., Brabec, M., Malý, M., \& Valeriánová, A. (2020). Long-term trends in fog occurrence in the Czech Republic, Central Europe. Science of the Total Environment, 711, 135018.

Johansson, E., Spangenberg, J., Gouvêa, M. L., \& Freitas, E. D. (2013). Scale-integrated atmospheric simulations to assess thermal comfort in different urban tissues in the warm humid summer of São Paulo, Brazil. Urban Climate, 6, 24-43. https://doi.org/10.1016/j.uclim.2013.08.003.

Klemm, O., \& Lin, N. H. (2016). What causes observed fog trends: air quality or climate change? Aerosol and Air Quality Research, 16, 1131-1142. https://doi.org/10.4209 /aaqr.2015.05.0353.

Kumar, P., de Fatima Andrade, M., Ynoue, R. Y., Fornaro, A., de Freitas, E. D., Martins, J., Martins, L. D., Albuquerque, T., Zhang, Y., \& Morawska, L. (2016). New directions: From biofuels to wood stoves: the modern and ancient air quality challenges in the megacity of São Paulo. Atmospheric Environment. https://doi.org/10.1016/j.atmosenv.2016.05.059.

LaDochy, S., \& Witiw, M. (2012). The continued reduction in dense fog in the Southern California region: possible causes. Pure and Applied Geophysics, 169, 1157-1163.

Lucon, O., \& Goldemberg, J. (2010). São Paulo-the "other" Brazil: different pathways on climate change for state and federal governments. Journal of Environment \& Development, 19, 335-357. https://doi.org/10.1177 /1070496510378092.

Maurer, M., Klemm, O., Lokys, H. L., \& Lin, N. H. (2019). Trends of fog and visibility in Taiwan: climate change or air quality improvement? Aerosol and Air Quality Research, 19, 896-910. https://doi.org/10.4209/aaqr.2018.04.0152.

MMA (2013). Promot-Programa De Controle Da Poluição Do Ar Por Motociclos E Veículos Similares 2008-2009.

Nogueira, T., Cordeiro, D. d. S., Muñoz, R. A. A., Fornaro, A., Miguel, A. H., \& Andrade, M. F. (2015). Bioethanol and biodiesel as vehicular fuels in Brazil - assessment of atmospheric impacts from the long period of biofuels use. Biofuels: Status and Perspective. https://doi.org/10.5772 160944.

Noronha, F., Ribeiro, D., Teresa, D., Salinas, P., Soares, J., De Oliveira, A. P., De Miranda, R. M., Antunes, L., \& Souza, T. (2016). The evolution of temporal and spatial patterns of carbon monoxide concentrations in the metropolitan area of Sao Paulo, Brazil 2016. Advances in Meteorology. https://doi.org/10.1155/2016/8570581.

Peel, M. C., Finlayson, B. L., \& McMahon, T. A. (2007). Updated world map of the Köppen-Geiger climate classification. Hydrology and Earth System Sciences, 11, 1633-1644. https://doi.org/10.1002/ppp.421.
Pérez-Martínez, P. J., de Fátima Andrade, M., \& De Miranda, R. M. (2015). Traffic-related air quality trends in São Paulo, Brazil. Journal of Geophysical Research - Atmospheres. https://doi.org/10.1002/2014JD022812.

Prefeitura da Cidade de São Paulo (2012). Action plan of the city of São Paulo for mitigation and adaption climate change 66, 37-39. https://www.c40.org/case_studies/action-plan-formitigation-and-adaptation-to-climate-change.

Prefeitura da Cidade de São Paulo (2018). Lei N ${ }^{\circ}$ 16.802/ 2018. http://legislacao.prefeitura.sp.gov.br/leis/lei-16802-de-18de-janeiro-de-2018/detalhe.

Prefeitura da Cidade de São Paulo (2020). Programa de Metas 2019 / 2020 2019-2021. Resouce document, https://www. prefeitura.sp.gov.br/cidade/secretarias/upload/Programa $\% 20$ Metas\%202019-2020_texto.pdf, Accessed 11 Novembr 2019.

Seinfeld, J. H., \& Pandis, S. N. (2006). Atmospheric chemistry and physics (2nd ed.). Hoboken: Wiley.

Silveira, V., Carvalho, B., Freitas, E. D., Martins, L. D., Martins, J. A., Mazzoli, C. R., \& De Fá Tima Andrade, M. (2015). Air quality status and trends over the metropolitan area of São Paulo, Brazil as a result of emission control policies. Environmental Science \& Policy, 47, 68-79. https://doi. org/10.1016/j.envsci.2014.11.001.

UCLA - Statistical Consulting Group, n.d. FAQ: What are pseudo R-squareds? [WWW document]. URL https://stats.idre.ucla. edu/other/mult-pkg/faq/general/faq-what-are-pseudo-rsquareds/, Accessed 22 November 2019.

Vara-Vela, A., Andrade, M. F., Kumar, P., Ynoue, R. Y., \& Muñoz, A. G. (2016). Impact of vehicular emissions on the formation of fine particles in the São Paulo metropolitan area: a numerical study with the WRF-Chem model. Atmospheric Chemistry and Physics, 16. https://doi.org/10.5194/acp-16777-2016.

Vasconcellos, P. C., Gonçalves, F. L. T., Avila, S. G., Censon, V. K., \& Bauer, H. (2018). The chemical composition of winter fogs at São Paulo highway sites. Journal of the Brazilian Chemical Society, 29, 1951-1958. https://doi.org/10.21577 /0103-5053.20180072.

Vautard, R., Yiou, P., \& Van Oldenborgh, G. J. (2009). Decline of fog, mist and haze in Europe over the past 30 years. Nature Geoscience, 2, 115-119. https://doi.org/10.1038/ngeo414.

Vemado, F., José, A., \& Filho, P. (2016). Severe weather caused by heat island and sea breeze effects in the metropolitan area of São Paulo, Brazil. Advances in Meteorology. https://doi. org/10.1155/2016/8364134.

WMO (2017). International Cloud Atlas, Manual on the observation of clouds and other meteors. Resource document.. (WMO-No. 407). https://cloudatlas.wmo.int/home.html. Accessed 21 November 2019.

Zürich, U. (ed.) (2018). Methodenberatung - Logistische Regression. Resource document. Universität Zürich https://www.methodenberatung.uzh.ch/de/datenanalyse_ spss/zusammenhaenge/lreg.html\#3.4._Signifikanz_des_Regressionsmodells, Accessed 20 September 2019.

Publisher's Note Springer Nature remains neutral with regard to jurisdictional claims in published maps and institutional affiliations. 